\title{
Photosynthesis and growth in macroalgae: linking functional-form and power-scaling approaches
}

\author{
Carmen B. de los Santos*, J. Lucas Pérez-Lloréns, Juan J. Vergara \\ Department of Biology, University of Cádiz, PO Box 40, 11510 Puerto Real (Cádiz), Spain
}

\begin{abstract}
Grouping species into functional-form groups and measuring directly their surface area to volume ratio are 2 common approaches to forecast primary production of marine macroalgae. A link between the functional-form model (FFM) and the power-scaling approach (PSA) for a wide variety of marine macroalgae has been attempted for the first time in the present work. To test both approaches, thalli of 44 species of marine benthic macroalgae were collected from intertidal zones adjacent to Cádiz Bay. Metabolic rates, tissue nutrient content, surface area to biomass ratio (SA/B) and specific growth rates were measured for these species. PSA slopes were close to $2 / 3$ power for growth rate, while metabolic rates scaled very close to, or matched, $3 / 4$ power. The FFM descriptive model provided similar results to the PSA when it was transformed to a numerical model through the SA/B ratio. Even though both models appear to be valid, the problems derived from species allocation into morphological groups, and other previous criticisms, make the direct use of SA/B ratios more suitable for representing primary production in macroalgal functional groups in numerical models of coastal ecosystems.
\end{abstract}

KEY WORDS: Functional form - Cádiz Bay · Marine macroalgae $\cdot$ Photosynthesis - Primary production $\cdot$ Surface area to biomass ratio $(\mathrm{SA} / \mathrm{B}) \cdot$ Scaling $\cdot$ Specific thallus area

\section{INTRODUCTION}

Macroalgae are the dominant organisms in most rocky-shore habitats and in certain soft-bottom coastal environments. Marine macrophytes play key structural and functional roles, since they support considerable biodiversity and can contribute to primary production and biogeochemical cycles (Charpy-Roubaud \& Sournia 1990, Mann 2000, Gattuso et al. 2006). Thus, models of primary production in the coastal ocean need to include the macroalgal compartment in those habitats dominated by these organisms. However, it is unlikely that individual species will ever be considered in models, especially when diversity is high and taxonomy is difficult. Therefore, general statements and simplifications would allow macroalgal processes to be added to numerical models, in a similar manner to the functional-type approach in phytoplankton models.

In the literature, 2 approaches to the simplification of macroalgal communities are commonly reported. The first approach aims at predicting macroalgal 'productivity-related ecological processes' by grouping algae according to their morphological attributes (Littler \& Littler 1980, Littler \& Arnold 1982, Steneck \& Watling 1982). This model, the so-called functional-group or functional-form model (FFM), sorts macroalgae into several groups: sheet-like, filamentous, coarsely branched, thick leathery, jointed calcareous, and crustose. Among the established groups, the ecological or physiological functions are inferred or assumed to be correlated. For instance, sheet-like forms are supposed to be more productive than encrusting ones (see Padilla \& Allen 2000 and references therein). However, the FFM descriptive model has received many criticisms: (1) the potential, high morphological variability within a functional-form group or even for a single species (see Padilla \& Allen 2000); (2) the ambiguity associated with the definition of functional-form groups when applied to species (Phillips et al. 1997); (3) the variable assignment of certain species to a given group 
depending on the study or even the researchers (Phillips et al. 1997); and (4) the use of categorical variables as morphological groups.

A further approach is the use of power laws to describe the relationship between 2 biologically continuous variables. The most widely reported power law function in nature is the allometric law (Brown \& West 2000, Niklas 1994, 2004): $Y=Y_{0} M^{b}$, where $Y$ is an attribute (e.g. metabolic rate), $Y_{0}$ is the scaling coefficient, $M$ is the body mass, and $b$ is the scaling exponent. This relationship is applied for a broad range of physiological processes (e.g. photosynthesis, respiration, growth, etc.) over a range of organism sizes and types (Banse 1982, Raven \& Kübler 2002, Reich et al. 2006). Thus, scaling relationships would make feasible the forecasting of the potential production of plant populations and the energy budget of an ecosystem when the size spectrum of organisms is known (Nielsen \& Sand-Jensen 1990). Accordingly, the proposed metabolic theory of ecology (MTE; Brown et al. 2004) provides predictions of functional processes, as well as the responses of communities and ecosystems from thoroughly understood physiological principles governing the allometric scaling of organism metabolism.

However, body size or biomass is often difficult to determine in macroalgae at an individual scale, because either they lack a fixed mature size or many macroalgae are colonial species. In such cases, alternative continuous measurable variables, such as the surface area to volume ratio (SA/V), the surface area to biomass ratio (SA/B, also known as specific thallus area, STA), or thallus thickness, have been widely and successfully used (Nielsen \& Sand-Jensen 1990, Enríquez et al. 1995, 1996, Nielsen et al. 1996, Raven \& Kübler 2002, Alwyn \& Rees 2007). In fact, these variables relate the exchange potential (i.e. energy-light absorption and nutrient assimilation) of a given photosynthetic organism to its volume or biomass (Sournia 1982).

Studies about the scaling of functional processes (mainly photosynthesis, respiration, nutrient uptake, and growth) using factors such as SA/V, SA/B, or thickness are mostly compilations (Enríquez et al. 1996, Nielsen et al. 1996, Alwyn \& Rees 2007) or a combination of original work and published data (Nielsen \& Sand-Jensen 1990). Additionally, those containing experimental work are scarce: there is a wide spatial and temporal dispersion in the species collected (Littler \& Arnold 1982); the studies are restricted to a single algal genus (Gacia et al. 1996); or photosynthesis, respiration, and growth data are not jointly provided.

Our purposes in the present study were, for a wide variety of marine macroalgae: (1) to test the soundness of the functional-form model (Littler \& Littler 1980) for net photosynthesis, respiration, and growth rates; (2) to test the hypothesis that these physiological rates should scale with the SA/B ratio, following a powerscaling approach similar to allometric law; and (3) to establish a link between these 2 models.

\section{MATERIALS AND METHODS}

Field sampling and algal material. Forty-four marine co-occurring macroalgae species (22 Rhodophyta, 10 Phaeophyceae, and 12 Chlorophyta; Table 1) were collected from the intertidal zone at 3 locations in Cádiz Bay (southern Spain, $36^{\circ} 28^{\prime} \mathrm{N}, 6^{\circ} 15^{\prime} \mathrm{W}$ ). Firstly, 2 contrasting open rocky-shore habitats; one relatively sheltered (La Caleta), the other moderately exposed (El Chato) were sampled, and, secondly, a soft-sediment, semi-enclosed bay (Santibáñez tidal flat) was sampled. The sampling was designed for testing the feasibility of comparisons among species according to Rosenberg \& Ramus (1984). Moreover, the sampling was designed to encompass the broadest range of morphological variability in the sampled areas. Once collected, algae were immediately transported to the laboratory in an ice chest. Then, sediment, debris, and visible epiphytes were removed. Afterwards, specimens were identified to genus or species level, when possible. Before measurements, algae were kept $(5 \mathrm{~h}$ maximum) in aerated aquaria (filled with freshly collected sea-water from the sampling site), within a temperature- and light-controlled incubation chamber (D-1400-3BL, ASL) at dim light and $20^{\circ} \mathrm{C}$.

Assignment of species to functional-form groups. Species were categorized a priori into 6 functionalform groups according to Littler \& Littler (1980): sheetlike (G1) (thin, tubular, and sheet-like), filamentous (G2) (delicately branched), coarsely branched (G3), thick leathery (G4), jointed calcareous (G5), and crustose (G6). In Littler's classical approach, the groups were 'ranked from the hypothesized highest to lowest primary productivity based on morphology, size, and surface to volume ratio' (Littler \& Arnold 1982). Additionally, morphology and internal structure were considered for the classification of the species (Littler et al. 1983). Nevertheless, some species did not clearly fit into any defined group. In such cases, they were assigned to the closest functional-form group by affinity to their morphological and hypothesized physiological characteristics (Table 2).

Photosynthesis and dark respiration rates. The oxygen exchange method was used to estimate carbonspecific metabolic rates of the species sampled (3 replicates each). Incubations were conducted in $62 \mathrm{ml}$ jars with filtered natural seawater $(\mathrm{pH} 8.3$, salinity $=35)$. Jars were carefully sealed to avoid bubbles and placed 
in a temperature- and light-controlled incubation chamber (D-1400-3BL, ASL) at $20^{\circ} \mathrm{C}$. The seawater reservoir to fill the incubation jars was maintained at $20^{\circ} \mathrm{C}$ in a thermostatic bath (Pselecta) connected to a cooling unit (Pselecta, Tectron BIO). Light was pro- vided by fluorescent tubes (Philips TDL 18W/865), and photon flux was measured with a quantum meter LI 193-SA (LiCor) with a mounted $4 \pi \mathrm{PAR}$ (400 to $700 \mathrm{~nm}$ ) sensor connected to a data logger (LI-1000, LiCor).

Table 1. Inventory of species included in the present study, grouped into different functional-form groups. Taxonomic group. P: Phaeophyceae; R: Rhodophyta; C: Chlorophyta; and geographical location, Ch: El Chato rocky-shore; Ca: La Caleta rockyshore; St: Santibáñez tidal flat, are indicated. Net photosynthetic (NP) rates and mean specific growth $(\mu)$ for each species are shown $(\mathrm{n}=3)$

\begin{tabular}{|c|c|c|c|}
\hline Species & Group, location & $\mathrm{NP}\left(\mathrm{mg} \mathrm{C} \mathrm{g}{ }^{-1} \mathrm{C} \mathrm{h}^{-1}\right)$ & $\mu\left(\% \mathrm{~d}^{-1}\right)$ \\
\hline \multicolumn{4}{|l|}{ G1: Sheet-like (6) } \\
\hline Dictyota dichotoma (Hudson) J. V. Lamouroux & $\mathrm{P}, \mathrm{Ch}$ & 18.11 & 7.89 \\
\hline Dictyota dichotoma var. intricata (C. Agardh) Greville & $\mathrm{P}, \mathrm{Ch}$ & 5.89 & 3.78 \\
\hline Dictyopteris polypodioides (A. P. de Candolle) J. V. Lamouroux & $\mathrm{P}, \mathrm{Ch}$ & 5.99 & 4.34 \\
\hline Ulva clathrata (Roth) C. Agardh & $\mathrm{C}, \mathrm{Ca}$ & 26.29 & nd \\
\hline Ulva intestinalis Linnaeus & $\mathrm{C}, \mathrm{Ca}$ & 16.72 & 6.87 \\
\hline Ulva sp. & $\mathrm{C}, \mathrm{Ca}$ & 6.44 & 6.93 \\
\hline \multicolumn{4}{|l|}{ G2: Filamentous (4) } \\
\hline Asparagopsis armata Harvey & $\mathrm{R}, \mathrm{Ca}$ & 9.44 & nd \\
\hline Bornetia secundiflora (J. Agardh) Thuret & $\mathrm{R}, \mathrm{Ch}$ & 6.71 & 2.33 \\
\hline Pedobesia simplex (Meneghini ex Kützing) M. J. Wynne \& Leliaert & $\mathrm{C}, \mathrm{Ch}$ & 7.07 & 2.98 \\
\hline Cladophora laetevirens (Dillwyn) Kützing & $\mathrm{C}, \mathrm{Ca}$ & 6.70 & 5.26 \\
\hline \multicolumn{4}{|l|}{ G3: Coarsely branched (24) } \\
\hline Chondracanthus acicularis (Roth) Fredericq & $\mathrm{R}, \mathrm{Ch}$ & 3.75 & 3.44 \\
\hline Gymnogongrus crenulatus (Turner) J. Agardh & $\mathrm{R}, \mathrm{Ch}$ & 3.61 & 2.29 \\
\hline Phyllophora crispa (Hudson) P. S. Dixon & $\mathrm{R}, \mathrm{Ch}$ & 5.41 & 2.15 \\
\hline Schottera nicaeënsis (J. V. Lamouroux ex Duby) Guiry \& Hollenberg & $\mathrm{R}, \mathrm{Ca}$ & 6.58 & nd \\
\hline Hypnea musciformis (Wulfen) J. V. Lamouroux & $\mathrm{R}, \mathrm{Ch}$ & 7.85 & 5.03 \\
\hline Pterosiphonia sp. & $\mathrm{R}, \mathrm{Ca}$ & 4.05 & 2.32 \\
\hline Rytiphlaea tinctoria (Clemente \& Rubio) C. Agardh & $\mathrm{R}, \mathrm{Ch}$ & 1.99 & 3.63 \\
\hline Halopithys incurva (Hudson) Batters & $\mathrm{R}, \mathrm{Ch}$ & 4.96 & 2.48 \\
\hline Osmundea pinnatifida (Hudson) Stackhouse & $\mathrm{R}, \mathrm{Ca}$ & 8.43 & 1.68 \\
\hline Chondria sp. & $\mathrm{R}, \mathrm{Ch}$ & 6.73 & 3.99 \\
\hline Halurus equisetifolius (Lightfoot) Kützing & $\mathrm{R}, \mathrm{Ch}$ & 1.19 & 2.19 \\
\hline Gelidium spinosum (S. G. Gmelin) P. C. Silva & $\mathrm{R}, \mathrm{Ch}$ & 2.43 & 4.56 \\
\hline Pterocladiella capillacea (S. G. Gmelin) Santelices \& Hommersand & $\mathrm{R}, \mathrm{Ch}$ & 2.13 & 3.22 \\
\hline Gracilariopsis longissima (S. G. Gmelin) Steentoft, L. M. Irvine \& Farnham & $\mathrm{R}, \mathrm{St}$ & 3.37 & 4.69 \\
\hline Plocamium cartilagineum (Linnaeus) P. S. Dixon & $\mathrm{R}, \mathrm{Ch}$ & 11.60 & 1.61 \\
\hline Botryocladia botryoides (Wulfen) Feldmann & $\mathrm{R}, \mathrm{Ch}$ & 3.47 & 1.76 \\
\hline Liagora viscida (Forsskål) C. Agardh & $\mathrm{R}, \mathrm{Ch}$ & 3.61 & 2.03 \\
\hline Stypocaulon scoparium (Linnaeus) Kützing & $\mathrm{P}, \mathrm{Ch}$ & 2.07 & 2.93 \\
\hline Cladostephus spongiosus (Hudson) C. Agardh & $\mathrm{P}, \mathrm{Ch}$ & 3.55 & 3.22 \\
\hline Colpomenia peregrina Sauvageau & $\mathrm{P}, \mathrm{Ch}$ & 5.67 & 3.34 \\
\hline Codium sp. & $\mathrm{C}, \mathrm{St}$ & 2.31 & 1.34 \\
\hline Codium decorticatum (Woodward) M. A. Howe & $\mathrm{C}, \mathrm{Ch}$ & 2.78 & 2.09 \\
\hline Flabellia petiolata (Turra) Nizamuddin & $\mathrm{C}, \mathrm{Ch}$ & 3.97 & 2.9 \\
\hline Caulerpa prolifera (Forsskål) J. V. Lamouroux & $\mathrm{C}, \mathrm{St}$ & 1.95 & 2.22 \\
\hline \multicolumn{4}{|l|}{ G4: Thick leathery (5) } \\
\hline Peyssonnelia sp. & $\mathrm{R}, \mathrm{Ch}$ & 1.78 & 2.49 \\
\hline Padina pavonica (Linnaeus) Thivy & $\mathrm{P}, \mathrm{Ch}$ & 7.10 & 5.86 \\
\hline Fucus spiralis Linnaeus & $\mathrm{P}, \mathrm{St}$ & 2.62 & 4.06 \\
\hline Cystoseira tamariscifolia (Hudson) Papenfuss & $\mathrm{P}, \mathrm{Ch}$ & 2.93 & 2.88 \\
\hline Sargassum vulgare C. Agardh & $\mathrm{P}, \mathrm{Ch}$ & 6.72 & 2.1 \\
\hline \multicolumn{4}{|l|}{ G5: Jointed calcareous (2) } \\
\hline Jania rubens (Linnaeus) J. V. Lamouroux & $\mathrm{R}, \mathrm{Ch}$ & 3.27 & 1.83 \\
\hline Corallina officinalis Linnaeus & $\mathrm{R}, \mathrm{Ca}$ & 2.62 & 1.91 \\
\hline \multicolumn{4}{|l|}{ G6: Crustose (3) } \\
\hline Codium bursa (Linnaeus) C. Agardh & $\mathrm{C}, \mathrm{Ch}$ & 1.13 & 0.56 \\
\hline Codium adhaerens C. Agardh & $\mathrm{C}, \mathrm{Ch}$ & 0.50 & nd \\
\hline Valonia utricularis (Roth) C. Agardh & $\mathrm{C}, \mathrm{Ch}$ & 6.67 & 0.62 \\
\hline
\end{tabular}


Table 2. Rationale for assignment of some species into functional-form groups

\begin{tabular}{|c|c|c|}
\hline Species & Group & Justification \\
\hline Asparagopsis armata & G2 & Overall morphology resembles filamentous algae \\
\hline Bornetia secundiflora & G2 & Thallus of regular hollow sections, assigned to G2 for analogy to filamentous algae \\
\hline Pedobesia simplex & G2 & As the previous species \\
\hline Botryocladia botryoides & G3 & Cylindrical, hollow thallus with a multiaxial, pseudoparenchymatous structure \\
\hline Codium decorticatum & G3 & $\begin{array}{l}\text { This alga is coenocytic and, therefore, unlike any group. Assigned to G3 (coarsely } \\
\text { branched) due to overall morphology. }\end{array}$ \\
\hline Caulerpa prolifera & G3 & $\begin{array}{l}\text { This alga is coenocytic and, therefore, unlike any group. Assigned to G3 (coarsely } \\
\text { branched) as it presents several proliferations that resemble branches }\end{array}$ \\
\hline Codium bursa & G6 & $\begin{array}{l}\text { This alga is coenocytic and, therefore, unlike any group. Assigned to G6 (crustose) due to } \\
\text { its physiological characteristics }\end{array}$ \\
\hline Codium adhaerens & G6 & As the previous species \\
\hline Valonia utricularis & G6 & Assigned to G6 as it most closely appears to upholster the rocks as crustose algae do \\
\hline
\end{tabular}

Complete darkness and light incubations were conducted on the same thallus fragment measuring $\mathrm{O}_{2}$ evolution (25 min each) for the estimation of dark respiration rate $\left(R_{\mathrm{d}}\right)$ and net photosynthesis rate (NP), respectively. In both cases, jars were continuously stirred using an orbital shaker (Pselecta, Rotabit). Prior to incubations in the darkness, the water was vigorously stirred to reach oxygen saturation levels, whereas water was bubbled with nitrogen to get lower $\mathrm{O}_{2}$ concentrations (about $40 \%$ saturation) before starting incubations in the light. Initial and final $\mathrm{O}_{2}$ concentrations in seawater were measured with an oxygen electrode (OXI 45 Crison Cell OX). Irradiance in light incubations was $242 \mu \mathrm{mol}$ photons $\mathrm{m}^{-2} \mathrm{~s}^{-1}$, and it was enhanced by using highly reflective aluminium foil at the shelves of the incubation chamber. This value is close to the mean irradiance saturation point for thallus pieces or phytoelements $\left(250 \mu \mathrm{mol}\right.$ photons $\mathrm{m}^{-2} \mathrm{~s}^{-1}$; Binzer \& Sand-Jensen 2006). Thus, it was also assumed to be saturating for the majority of the assayed species.

At the end of the incubations, thalli were weighed and oven dried $\left(60^{\circ} \mathrm{C}\right.$ to complete dryness) to calculate dry weight to fresh weight ratios (DW/FW). The dry weight of the calcareous species included the carbonates associated with the cell wall. Then, dry algal material was used to determine $\mathrm{C}$ and $\mathrm{N}$ elemental composition in a FlashEA1112 Elemental analyser (ThermoFinnigan). Carbon-specific net photosynthesis and respiration rates ( $\mathrm{NP}$ and $R_{\mathrm{d}}, \mathrm{mg} \mathrm{C} \mathrm{g}^{-1} \mathrm{C} \mathrm{h}^{-1}$ ) were computed from oxygen evolution, biomass, and internal carbon content assuming a photosynthetic quotient of 1 . In addition, the carbon-specific gross photosynthesis (GP) was estimated according to the equation $\mathrm{GP}=\mathrm{NP}+R_{\mathrm{d}}$. As a result, the gross photosynthetic rates may have been slightly underestimated, because respiration rate was measured in the darkness.

Growth rate measurements. Growth rate was estimated from weight gains under non-limiting condi- tions. First of all, thalli of each species were carefully blotted and weighed at the beginning of the incubations. Then, the biological materials were incubated within 11 Erlenmeyer flasks $(n=3)$, using artificial seawater $(\mathrm{S}=35)$ prepared from a sea salt mixture (hw Marinemix professional, Wiegandt). At the same time, the artificial seawater was enriched with $30 \mathrm{\mu M} \mathrm{NO}_{3}{ }^{-}$ and $2 \mu \mathrm{M} \mathrm{H}_{2} \mathrm{PO}_{4}^{-}$(final concentrations), and an airpumping system provided homogenisation and gentle movement of the thalli. Next, the Erlenmeyer flasks were randomly placed within the incubation chamber (D-1400-3BL, ASL), at $20^{\circ} \mathrm{C}, 190$ to $220 \mu \mathrm{mol}$ photons $\mathrm{m}^{-2} \mathrm{~s}^{-1}$, and under a $12 \mathrm{~h}$ light:12 h dark cycle. Also, highly reflective aluminium foil was used on the shelf of the incubation chamber to achieve homogeneous light. During the incubations, all thalli were collected every 3 to $4 \mathrm{~d}$, cleaned of epiphytes when necessary, carefully blotted, weighed, and returned to clean Erlenmeyer flasks with freshly prepared nutrientenriched artificial seawater. Then they were randomly relocated in the chamber. The incubations lasted between 13 and 20 d (depending upon the species); afterwards the thalli were collected and weighed. The specific growth rate $(\mu)$ was determined by calculating the slope of the regression line through the napierian logarithms $(\mathrm{ln})$ of the fresh weight during the exponential growth phase, which normally started after a variable lag phase.

Estimation of specific thallus area. The STA or SA/B ratio $\left(\mathrm{cm}^{2} \mathrm{~g}^{-1} \mathrm{FW}\right)$ of several species was estimated by image analysis of thalli and the corresponding fresh weight. This variable was preferred over the SA/V ratio due to the inherent difficulties arising from the measurement of volume in small, delicately branched species. To measure the surface area, the projected 2-dimensional area of each thallus was estimated with Image J 1.36b software (Wayne Rasband, National Institute of Health). Thus, the total surface area of each 
sample was computed by multiplying the projected area by $\pi$ (for cylindrical thallus portions), by 4 (spherical portions), and by 2 (for thin, flat portions) (modified from Gacia et al. 1996). Depending on the size, a precision balance (Denver Instrument Company AA-160) or precision microbalance (Sartourius PP2215) was used to weigh the thalli.

Data analyses. Data are presented as means and standard deviations $(n=3)$ for each species. Prior to analysis, all variables were $\log 10$-transformed to meet the assumption of homocedasticity for regression analyses (Sokal \& Rohlf 1981), and Lillifores tests were used to test the normality of the log10-transformed data. Correlations between variables were tested by the Pearson correlation coefficient. Reduced major axis (RMA) slopes were fitted to bivariated trait relationships of log-transformed variables using Type II linear regression, which is suggested for scaling analysis (La Barberra 1989). The slope of such a line represents the proportional (scaling) relationship and is equivalent to the scaling exponent of the power law. The significance of the slope was tested using a 2sample $t$-test. The data set (species within each group) was compared using 1-way ANOVA, followed by Tukey's Honestly Significant Difference (HSD) test for unequal numbers of samples. In all cases, the significance level was set at $5 \%$ probability.

\section{RESULTS}

\section{Metabolic rates}

NP rates and $R_{\mathrm{d}}$ rates varied over 2 orders of magnitude in the data set (44 species). Values of NP ranged from $0.5 \mathrm{mg} \mathrm{C} \mathrm{g}^{-1} \mathrm{Ch}^{-1}$ (Codium adhaerens) to $26.3 \mathrm{mg} \mathrm{C} \mathrm{g}^{-1} \mathrm{C}$ $\mathrm{h}^{-1}$ (Ulva clathrata), while $R_{\mathrm{d}}$ varied from $0.33 \mathrm{mg} \mathrm{C} \mathrm{g}^{-1} \mathrm{C} \mathrm{h}^{-1}$ (Codium bursa) to $5.1 \mathrm{mg} \mathrm{C} \mathrm{g}^{-1} \mathrm{C} \mathrm{h}^{-1}$ (Ulva clathrata). There was a strong tendency for both metabolic rates to decline among the functional-form groups (i.e. from G1 to G6) (Fig. 1A), being remarkably steeper for NP than for $R_{\mathrm{d}}$. The highest values were attained in the group of sheet-like (G1) and filamentous algae (G2), while the jointed calcareous (G5) and crustose species (G6) showed the lowest rates (Fig. 1A). Significant differences between consecutive groups were not found, except between extreme groups, i.e. sheet-like (G1) and crustose (G6) groups (post hoc Tukey's HSD test, $\alpha=0.05$ ). Central groups (G2 to G5) showed similar mean values.

\section{Growth rate}

Specific growth rates $(\mu)$ were estimated in 40 species as some of them (Codium adherens, Asparagopsis armata, and Schottera nicaeënsis) did not grow properly in the laboratory or there was not enough material for incubations (Ulva clathrata). Specific growth rates ranged from $0.56 \% \mathrm{~d}^{-1}$ (Codium bursa) to $7.89 \% \mathrm{~d}^{-1}$ (Dictyopteris polypodioides), measured from the biomass increase over time. Species from sheet-like (G1)
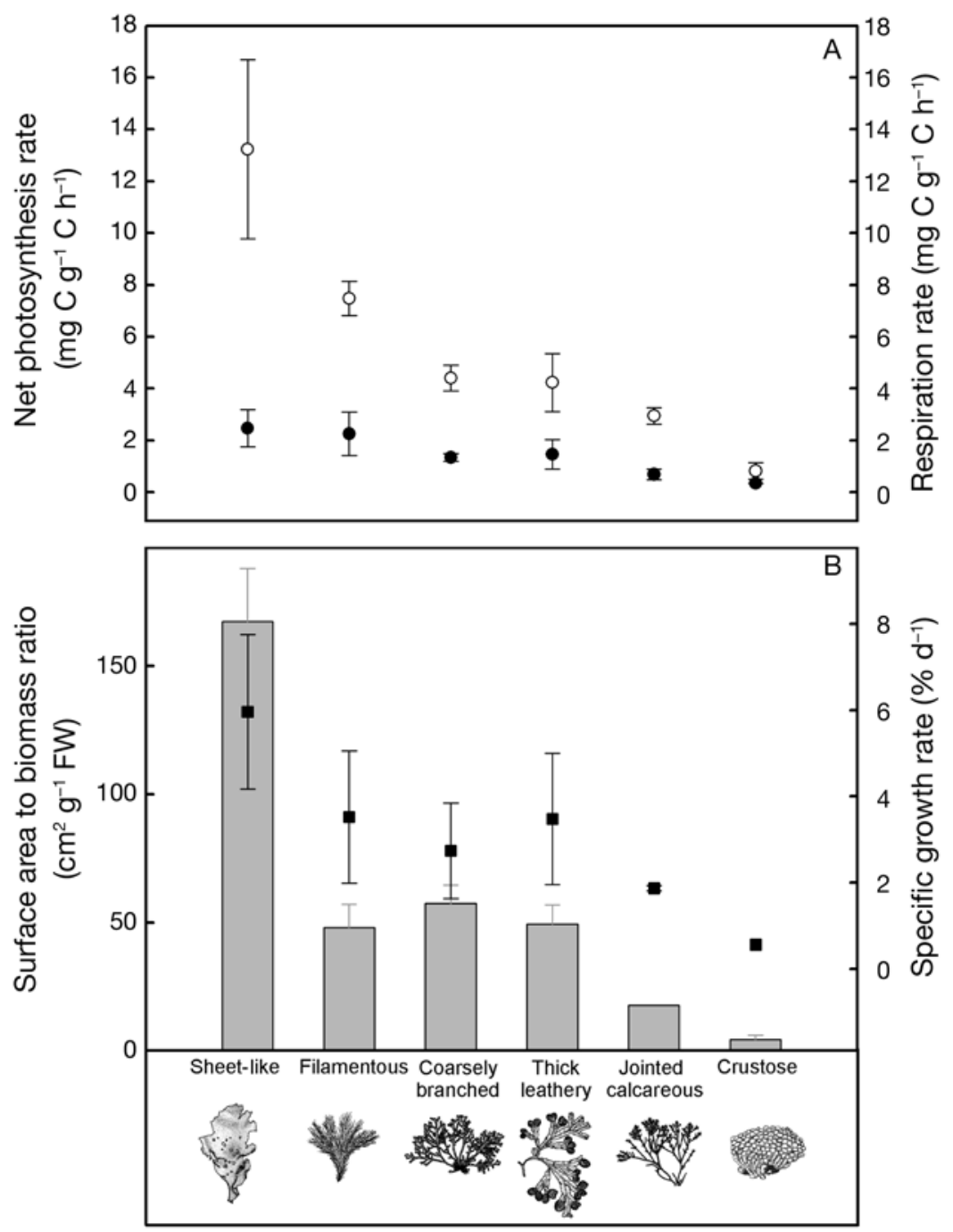

Fig. 1. Net photosynthesis, respiration (A) and growth rates (B) for species grouped according to the functional-form model (mean values $\pm S E ; n=3$ ). Bars indicate SA/B ratio. o: net photosynthesis rate; $\bullet$ : respiration rate; a: specific growth rate 
and filamentous (G2) groups tended to have higher growth rates (Fig. 1B), similar to the patterns recorded for NP and $R_{\mathrm{d}}$. From a taxonomical viewpoint, the orders Ulvales, Dictyotales, and Gelidiales presented the highest specific growth rates.

\section{Specific thallus area}

The SA/B ratio $\left(\mathrm{cm}^{2} \mathrm{~g}^{-1} \mathrm{FW}\right)$ was estimated in 37 species, and the value for Gracilariopsis longissima was taken from the literature (Andría 2001). Values ranged within 2 orders of magnitude. Overall, mean values dropped from G1 to G6, as metabolic and growth rates did (Fig. 1B). The maximum SA/B value was attained in the sheet-like macroalga Ulva sp. $\left(225 \mathrm{~cm}^{2} \mathrm{~g}^{-1} \mathrm{FW}\right)$, and the lowest one, in the balloon-like Codium bursa $\left(3 \mathrm{~cm}^{2} \mathrm{~g}^{-1} \mathrm{FW}\right)$.

\section{Power-scaling relationships}

Physiological variables were scaled to SA/B ratio through power functions, in the same way that they are scaled to size in allometric laws. Table 3 shows the reduced major axis equations and coefficients of determination for the described relationships. Fitting a relationship across log-transformed data, $\mu, \mathrm{NP}$, and $R_{\mathrm{d}}$ varied linearly with an increasing SA/B ratio, as described by their regression equations. Growth rate $\left(\mathrm{d}^{-1}\right)$ scaled to the SA/B ratio with an exponent of 0.64 $(95 \% \mathrm{CI}=0.63$ to 0.65$)$, showing a positive relationship. Similarly, there were strong positive relationships between log SA/B and log metabolic rates ( $R_{\mathrm{d}}$ and NP). The scaling exponents based on a RMA regression for these relationships were 0.75 (95\% CI $=0.73$ to 0.75 ) and $0.78(95 \% \mathrm{CI}=0.76$ to 0.80$)$, respectively. A relationship between nitrogen content and SA/B ratio was also found, scaling with a slope of $0.50(95 \% \mathrm{CI}=0.49$ to 0.50$)$. Fig. 2 shows the scatter plots of $\mu, \mathrm{NP}, R_{\mathrm{d}}$, and $\mathrm{N}$ content against SA/B ratio based on a log-scaled axis, with regression lines calculated by RMA regression analysis.

\section{Linking two approaches}

For the purpose of linking the functional-form model and power-scaling approach, the log-transformed mean values of physiological rates of each functionalform group were plotted against the log-transformed mean SA/B within the groups (Fig. 3). Thereby, the descriptive FFM and the PSA were comparable. Slope values for the transformed FFM were close to those from PSA, except for nitrogen content (Table 4).

\section{DISCUSSION}

Metabolic, as well as growth rates, are key variables in understanding primary production processes. Surprisingly, the bulk of published data usually deals with a few well-known genera, particularly Ulva, Gracilaria, or Fucus. In this context, the present study is a further contribution to the database of physiological variables, $\mathrm{SA} / \mathrm{B}$ ratio values, and scaling relationships in a wide

Table 3. Reduced major axis regression slopes for $\log _{10}$-transformed variables ( $y$-axis) versus $\log _{10}$-transformed SA/B ( $x$-axis) for power-scaling approach

\begin{tabular}{|c|c|c|c|c|c|c|}
\hline Variable & Slope & CI $(95 \%)$ & $\mathrm{p}(b=0)$ & $F$ & $\mathrm{n}$ & $\mathrm{R}^{2}$ \\
\hline Specific growth rate $\left(\% \mathrm{~d}^{-1}\right)$ & 0.64 & $0.63-0.65$ & $<0.001$ & 56.3 & 35 & 0.50 \\
\hline Net photosynthetic rate $\left(\mathrm{mg} \mathrm{C} \mathrm{g}^{-1} \mathrm{C} \mathrm{h}^{-1}\right)$ & 0.78 & $0.76-0.80$ & $<0.001$ & 35.4 & 38 & 0.25 \\
\hline Gross photosynthetic rate $\left(\mathrm{mg} \mathrm{C} \mathrm{g}^{-1} \mathrm{C} \mathrm{h}^{-1}\right)$ & 0.71 & $0.69-0.74$ & $<0.001$ & 33.8 & 34 & 0.27 \\
\hline Dark respiration rate $\left(\mathrm{mg} \mathrm{C} \mathrm{g}^{-1} \mathrm{C} \mathrm{h}^{-1}\right)$ & 0.75 & $0.74-0.75$ & $<0.001$ & 28.9 & 38 & 0.14 \\
\hline Nitrogen content (\% DW) & 0.50 & $0.49-0.50$ & $<0.001$ & 27.6 & 38 & 0.12 \\
\hline
\end{tabular}

Table 4. Reduced major axis regression slopes for $\log _{10}$-transformed variables ( $y$-axis) versus $\log _{10}$-transformed SA/B $(x$-axis) for transformed functional-form model

\begin{tabular}{|c|c|c|c|c|c|c|}
\hline Variable & Slope & CI $(95 \%)$ & $\mathrm{p}(b=0)$ & $F$ & $\mathrm{n}$ & $\mathrm{R}^{2}$ \\
\hline Specific growth rate $\left(\% \mathrm{~d}^{-1}\right)$ & 0.66 & $0.65-0.67$ & $<0.001$ & 87.6 & 6 & 0.95 \\
\hline Net photosynthetic rate $\left(\mathrm{mg} \mathrm{C} \mathrm{g}^{-1} \mathrm{C} \mathrm{h}^{-1}\right)$ & 0.76 & $0.76-0.77$ & $<0.001$ & 56.5 & 6 & 0.93 \\
\hline Gross photosynthetic rate $\left(\mathrm{mg} \mathrm{C} \mathrm{g}^{-1} \mathrm{C} \mathrm{h}^{-1}\right)$ & 0.73 & $0.72-0.73$ & $<0.001$ & 59.4 & 6 & 0.93 \\
\hline Dark respiration rate $\left(\mathrm{mg} \mathrm{C} \mathrm{g}^{-1} \mathrm{C} \mathrm{h}^{-1}\right)$ & 0.62 & $0.61-0.62$ & $<0.001$ & 38.2 & 6 & 0.90 \\
\hline Nitrogen content $(\%$ DW) & 0.27 & $0.26-0.28$ & $>0.001$ & 6.9 & 6 & 0.50 \\
\hline
\end{tabular}



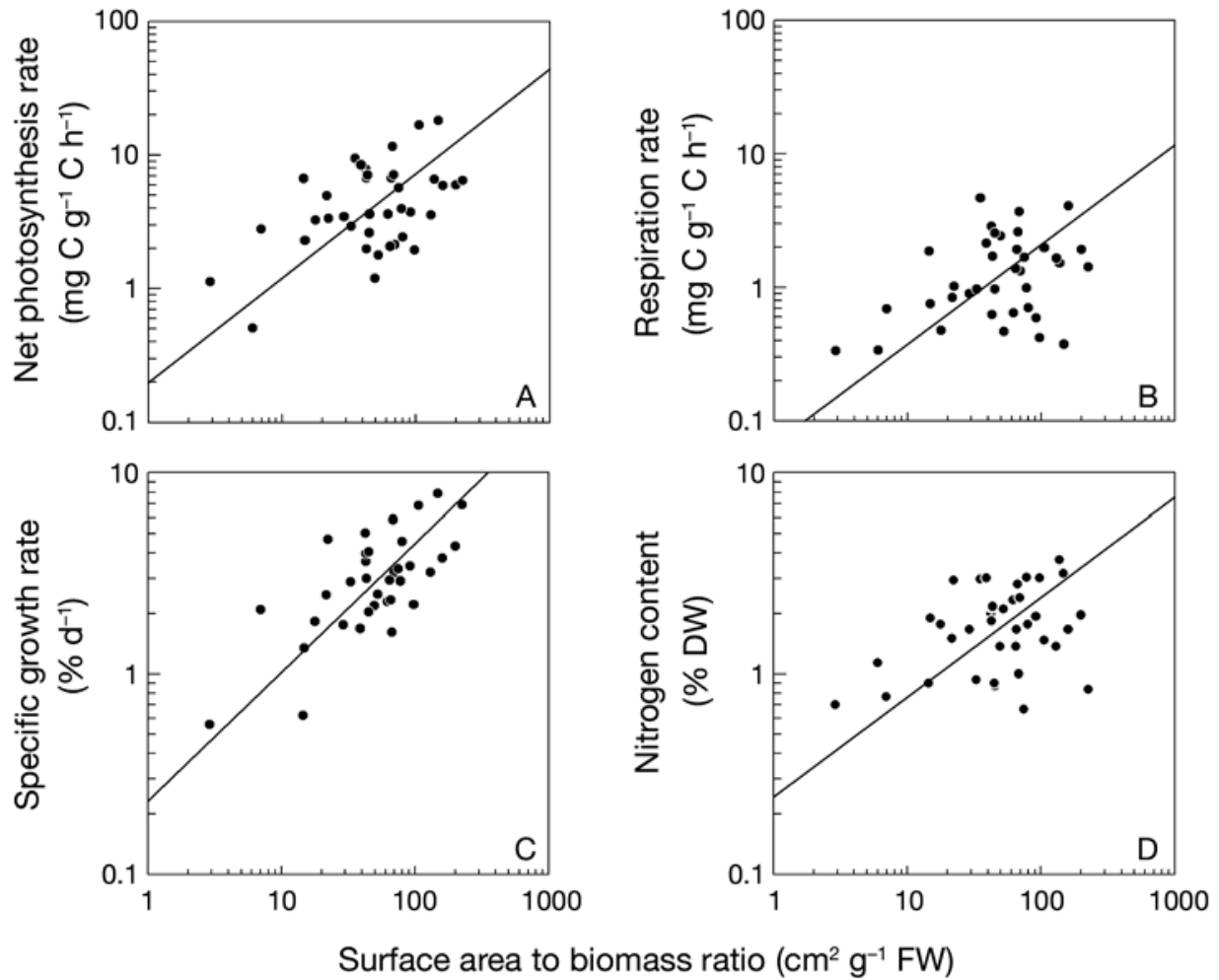

Fig. 2. Scaling relationships between physiological rates and SA/B ratio: (A) net photosynthesis rate, (B) respiration rate,

(C) specific growth rate, and (D) nitrogen content. Solid lines indicate a reduced major axis regression line
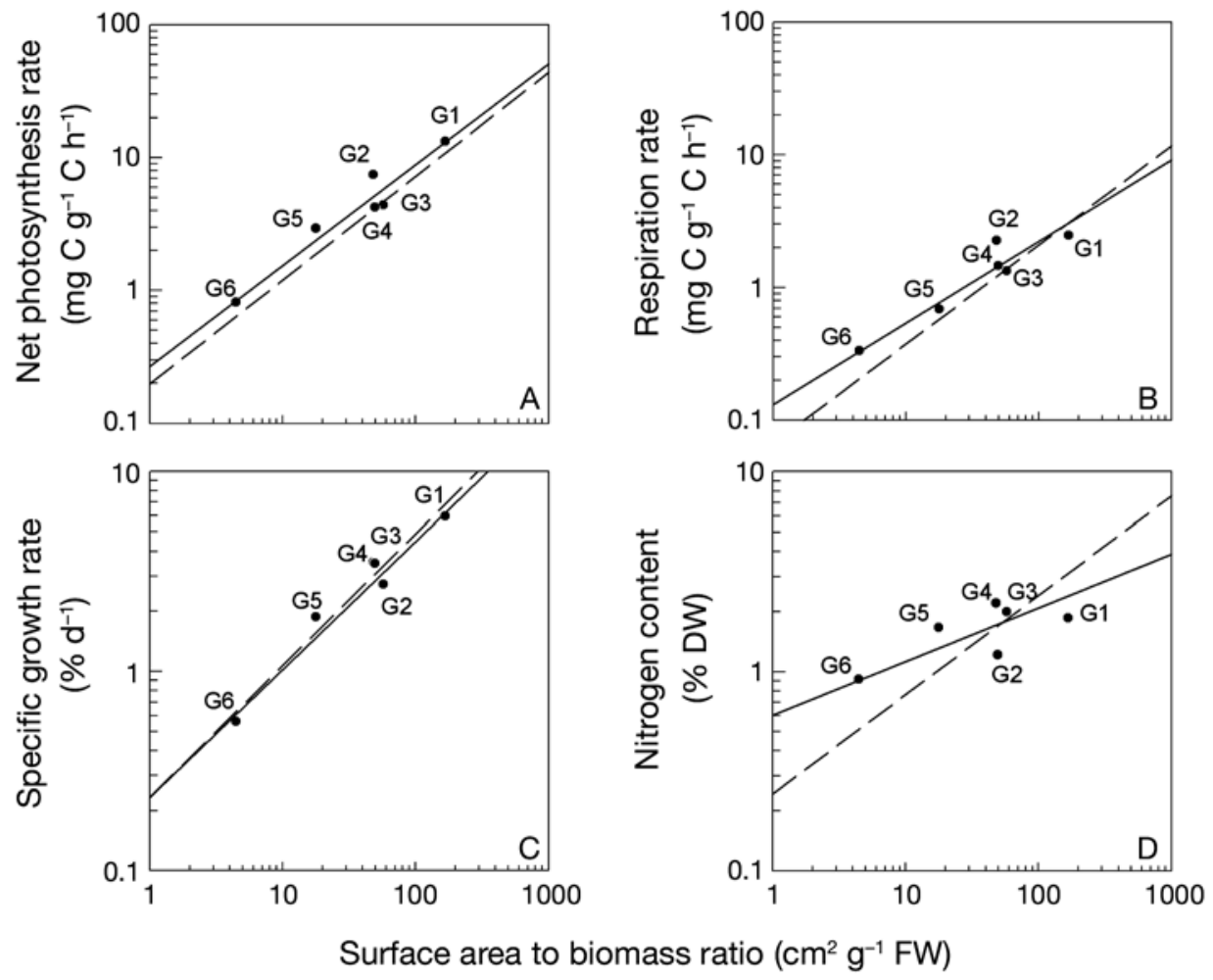

Fig. 3. Scaling relationships between physiological rates and SA/B ratios for mean values within each functional-form group: (A) net photosynthesis rate, (B) respiration rate, (C) specific growth rate and (D) nitrogen content. Dashed lines indicate a reduced major axis regression model over all species, while solid lines show the regression lines over the pair mean values for each functional-form group. G1: sheet-like; G2: filamentous; G3: coarsely branched; G4: thick leathery; G5: jointed calcareous; G6: crustose 
range of marine macroalgae from temperate waters, many of them being reported for the first time.

Two approaches to forecast marine macroalgal primary production were applied for a large pool of species. Firstly, the classification of the species into categorical groups was conducted according to the traditional work of Littler \& Littler (1980), the so-called functional-form model. Secondly, the power-scaling approach was considered to establish an empirical relationship between the SA/B ratio and the physiological rates. Finally, both approaches were related to each other through the SA/B ratio: this quotient is used as a scaling factor in PSA, while physiological processes depending on morphology, which is assumed to be related to the $\mathrm{SA} / \mathrm{V}$ or, in this case the $\mathrm{SA} / \mathrm{B}$ ratio, are described by the FFM

When applying the FFM, we found that the morphological groups (G1 to G6) were not statistically different, as categorical groups represent portions of a morphological continuum. However, those forms near the opposite ends of the morphological spectrum (G1 and G6) show significant differences in the predicted direction. Secondly, G2, G3, and G4 presented values very close to each other, probably due to their similar morphology. Finally, we found that some species do not conform to the general pattern. For instance, Cladostephus spongiosus, a species with a high SA/B ratio, did not show elevated growth or photosynthetic rates. In addition, Codium sp. and C. decorticatum did not fit into the coarsely branched group, as they showed metabolic and growth rates closer to species from the crustose group, where 2 congeneric species were categorized. Despite 18 previous studies claiming support for the FFM, as compared to only 2 critical works (Padilla \& Allen 2000), our results can only partially support the FFM approach. In fact, in some studies supporting the aforementioned models (e.g. Littler \& Littler 1984, Littler et al. 1987), the same grouping drawbacks were presented.

The second approach considered in the present study was the use of the SA/B ratio as a scaling factor. Enríquez et al. (1995) suggested the use of continuous scaling variables as descriptors of plant functional properties, as they present several advantages to the use of categorical variables for making quantitative predictions. Some of these descriptors are: SA/B, SA/V, and photosynthetic tissue thickness. In fact, all these morphological features are interconnected since the $\mathrm{SA} / \mathrm{B}$ ratio is related to the SA/V ratio by thallus density, and the latter is linked to thickness through empirical equations, as Enríquez et al. (1996) proposed. Slope values reported in the current work were close to those from the literature (Table 5). Whereas growth rate scaled to size close to $2 / 3$ power (Enríquez et al. 1996, present study), net photosynthesis rate scaled very close to, or even matched, 3/4 power. The steeper

Table 5. Comparison of scaling exponents for metabolic and growth rates with those reported in the literature

\begin{tabular}{|c|c|c|c|c|}
\hline Rate & Allometric factor & $\begin{array}{l}\text { Slope value (CI 95\% } \\
\text { or standard deviation) }\end{array}$ & Plant group & Source \\
\hline Maximum growth rate $\left(\mathrm{d}^{-1}\right)$ & $\mathrm{SA} / \mathrm{B}\left(\mathrm{cm} \mathrm{g}^{-1} \mathrm{FW}\right)$ & $0.64(0.63-0.65)$ & Macroalgae $(\mathrm{n}=35)$ & Present study \\
\hline Maximum growth rate $\left(\mathrm{d}^{-1}\right)$ & $\mathrm{SA} / \mathrm{V}\left(\mathrm{m}^{2} \mathrm{~m}^{-3}\right)$ & $0.66(0.61-0.72)$ & $\begin{array}{l}\text { Aquatic angiosperms }(\mathrm{n}=14) \\
\text { Macroalgae }(\mathrm{n}=34) \\
\text { Microalgae }(\mathrm{n}=44)\end{array}$ & $\begin{array}{l}\text { Nielsen \& Sand- } \\
\text { Jensen (1990) }\end{array}$ \\
\hline Maximum growth rate $\left(\mathrm{d}^{-1}\right)$ & Thickness (mm) & $-0.58( \pm 0.02)$ & $\begin{array}{l}\text { Phytoplankton }(\mathrm{n}=66) \\
\text { Macroalgae }(\mathrm{n}=250) \\
\text { Aquatic angiosperms }(\mathrm{n}=118) \\
\text { Terrestrial plants }(\mathrm{n}=265)\end{array}$ & Nielsen et al. (1996) \\
\hline $\begin{array}{l}\text { Respiration rate } \\
\left(\mathrm{mg} \mathrm{C} \mathrm{g}^{-1} \mathrm{C} \mathrm{h}^{-1}\right)\end{array}$ & $\mathrm{SA} / \mathrm{B}\left(\mathrm{cm} \mathrm{g}^{-1} \mathrm{FW}\right)$ & $0.75(0.73-0.75)$ & Macroalgae $(n=38)$ & Present study \\
\hline $\begin{array}{l}\text { Respiration rate } \\
\left(\mathrm{mg} \mathrm{C} \mathrm{g}^{-1} \mathrm{C} \mathrm{h}^{-1}\right)\end{array}$ & Thickness (mm) & $-0.33( \pm 0.035)$ & $\begin{array}{l}\text { Phytoplankton }(\mathrm{n}=66) \\
\text { Macroalgae }(\mathrm{n}=250) \\
\text { Aquatic angiosperms }(\mathrm{n}=118) \\
\text { Terrestrial plants }(\mathrm{n}=265)\end{array}$ & Enríquez et al. (1996) \\
\hline $\begin{array}{l}\text { Net photosynthetic rate } \\
\left(\mathrm{mg} \mathrm{C} \mathrm{g}^{-1} \mathrm{C} \mathrm{h}^{-1}\right)\end{array}$ & $\mathrm{SA} / \mathrm{B}\left(\mathrm{cm} \mathrm{g}^{-1} \mathrm{FW}\right)$ & $0.78(0.76-0.80)$ & Macroalgae $(\mathrm{n}=38)$ & Present study \\
\hline $\begin{array}{l}\text { Net photosynthetic rate } \\
\left(\mathrm{mg} \mathrm{C} \mathrm{g}^{-1} \mathrm{C} \mathrm{h}^{-1}\right)\end{array}$ & Thickness (mm) & $-0.49( \pm 0.03)$ & $\begin{array}{l}\text { Phytoplankton }(\mathrm{n}=66) \\
\text { Macroalgae }(\mathrm{n}=250) \\
\text { Aquatic angiosperms }(\mathrm{n}=118) \\
\text { Terrestrial plants }(\mathrm{n}=265)\end{array}$ & Enríquez et al. (1996) \\
\hline Nitrogen content (\% DW) & $\mathrm{SA} / \mathrm{B}\left(\mathrm{cm} \mathrm{g}^{-1} \mathrm{FW}\right)$ & $0.50(0.49-0.50)$ & Macroalgae (n=44) & Present study \\
\hline
\end{tabular}


slope for NP and $R_{\mathrm{d}}$ than for $\mu$ may be due to less efficient photosynthesis allocation in growth in those species with high SA/B ratios. The aforementioned studies analyse a wide spectrum of autotrophic organism sizes, so the value of the scaling slopes may vary from our work that only includes macroalgae.

Comparing the results of both approaches, it can be concluded that, for physiological properties (photosynthesis, respiration, and growth rates), FFM as well as PSA follow the same patterns. Despite the drawbacks of FFM, this descriptive model provided similar results to the PSA when it was transformed into a numerical model through the SA/B ratio. Therefore, both grouping marine macroalgae into functional-form groups and measuring their SA/B for power scaling seem to be reliable approaches to the same problem. Even though both models appear to be valid, the problems derived from species classification into morphological groups and other criticisms mentioned make the direct use of $\mathrm{SA} / \mathrm{B}$ ratios as a scaling factor more suitable for primary production predictions in marine macroalgal dominated ecosystems than grouping species into groups based on morphology. Thus, we conclude that the use of the SA/B ratio as a scaling factor is more appropriate for predicting primary production in marine macroalgal communities than using categorical groups.

The absence of empirical support for descriptive models such us FFM may be understood by examining other factors that influence the processes under consideration within functional-form groups. For instance, the dependence of physiological rate variability on local environmental conditions (Padilla \& Allen 2000) or phylogenetic relatedness (Felsenstein 1985, Starck 1998) should be examined in future studies.

To sum up, this study is an empirical contribution that will support macroecological studies aiming to synthesize data on growth and metabolic rates of primary producers in the coastal ocean. However, prediction of macroalgal community production based on the relationships described between SA/B and photosynthesis of a small section of thalli may be difficult. Upscaling from phytoelements to whole communities should include additional corrections for macroalgal density, absortion and self-shading, and irradiance distribution for a proper interpretation (Binzer \& SandJensen 2006).

Acknowledgements. This study was supported by the project CTM2005-00395/MAR from the Ministerio de Educación y Ciencia (MEC), now Ministerio de Ciencia e Innovación (MICINN). C.B.S. holds a FPU grant from MEC. The author thanks the editor and 2 anonymous reviewers for constructive comments, and B. Eizaga for helping with the academic English style.

\section{LITERATURE CITED}

Alwyn T, Rees V (2007) Metabolic and ecological constraints imposed by similar rates of ammonium and nitrate uptake per unit surface area at low substrate concentrations in marine phytoplankton and macroalgae. J Phycol 43: $197-207$

Andría J (2001) Mecanismos de adquisición de carbono en algas de la marisma de Los Toruños (bahía de Cádiz). Implicaciones ecológicas. $\mathrm{PhD}$ dissertation, Universidad de Cádiz, Cádiz

Banse K (1982) Cell volumes, maximal growth-rates of unicellular algae and ciliates, and the role of ciliates in the marine pelagial. Limnol Oceanogr 27:1059-1071

Binzer T, Sand-Jensen K (2006) Community photosynthesis of aquatic macrophytes. Limnol Oceanogr 51:2722-2733

Brown JH, West GB (2000) Scaling in biology. Oxford University Press, New York

Brown JH, Gillooly JF, Allen AP, Savage VM, West GB (2004) Toward a metabolic theory of ecology. Ecology 85: 1771-1789

Charpy-Roubaud C, Sournia A (1990) The comparative estimation of phytoplanktonic, microphytobenthic and macrophytobenthic primary production in the oceans. Mar Microb Food Webs 4:31-57

Enríquez S, Duarte CM, Sand-Jensen K (1995) Patterns in the photosynthetic metabolism of Mediterranean macrophytes. Mar Ecol Prog Ser 119:243-252

Enríquez S, Duarte CM, Sand-Jensen K, Nielsen SL (1996) Broad-scale comparison of photosynthetic rates across phototrophic organisms. Oecologia 108:197-206

$>$ Felsenstein J (1985) Phylogenies and the comparative method. Am Nat 125:1-15

Gacia E, Littler MM, Littler DS (1996) The relationships between morphology and photosynthetic parameters within the polymorphic genus Caulerpa. J Exp Mar Biol Ecol 204:209-224

Gattuso JP, Gentili B, Duarte CM, Kleypas JA, Middelburg JJ, Antoine D (2006) Light availability in the coastal ocean: impact on the distribution of benthic photosynthetic organisms and their contribution to primary production. BiogeoSciences 3:489-513

La Barberra M (1989) Analyzing body size as a factor in ecology and evolution. Annu Rev Ecol Syst 88:92-99

Littler MM, Arnold KE (1982) Primary productivity of marine macroalgal functional-form groups from southwestern North-America. J Phycol 18:307-311

> Littler MM, Littler DS (1980) The evolution of thallus form and survival strategies in benthic marine macroalgae: field and laboratory tests of a functional form model. Am Nat 116:25-44

> Littler MM, Littler DS (1984) Relationships between macroalgal functional form groups and substrata stability in a sub-tropical rocky-intertidal system. J Exp Mar Biol Ecol 74:13-34

Littler MM, Littler DS, Taylor PR (1983) Evolutionary strategies in a tropical barrier-reef system: functional-form groups of marine macroalgae. J Phycol 19:229-237

> Littler MM, Littler DS, Taylor PR (1987) Functional similarity among isomorphic life-history phases of Polycavernosa debilis (Rhodophyta, Gracilariaceae). J Phycol 23:501-505

Mann K (2000) Ecology of coastal waters with implications for management. Blackwell Science, Oxford

Nielsen SL, Sand-Jensen K (1990) Allometric scaling of maximal photosynthetic growth-rate to surface volume ratio. Limnol Oceanogr 35:177-181

Nielsen SL, Enríquez S, Duarte CM, Sand-Jensen K (1996) 
Scaling maximum growth rates across photosynthetic organisms. Funct Ecol 10:167-175

Niklas KJ (1994) Plant allometry: the scaling form and process. University of Chicago Press, Chicago, IL

Niklas KJ (2004) Plant allometry: Is there a grand unifying theory? Biol Rev Camb Philos Soc 79:871-889

Padilla DK, Allen BJ (2000) Paradigm lost: reconsidering functional form and group hypotheses in marine ecology. J Exp Mar Biol Ecol 250:207-221

Phillips JC, Kendrick GA, Lavery PS (1997) A test of a functional group approach to detecting shifts in macroalgal communities along a disturbance gradient. Mar Ecol Prog Ser 153:125-138

Raven JA, Kübler JE (2002) New light on the scaling of metabolic rate with the size of algae. J Phycol 38:11-16

Editorial responsibility: Rodney Forster,

Lowestoft, UK
Reich PB, Tjoelker MG, Machado JL, Oleksyn J (2006) Universal scaling of respiratory metabolism, size and nitrogen in plants. Nature 439:457-461

> Rosenberg G, Ramus J (1984) Uptake of inorganic nitrogen and seaweed surface-area-volume ratios. Aquat Bot 19: $65-72$

Sokal SR, Rohlf RR (1981) Biometry. Freeman, New York Sournia A (1982) Form and function in marine-phytoplankton. Biol Rev Camb Philos Soc 57:347-394

Starck JM (1998) Non-independence of data in biological comparisons. A critical appraisal of current concepts, assumptions, and solutions. Theory Biosci 117:109-138

Steneck RS, Watling L (1982) Feeding capabilities and limitation of herbivorous mollusks: a functional-group approach. Mar Biol 68:299-319

Submitted: January 7, 2008; Accepted: November 25, 2008 Proofs received from author(s): February 7, 2009 